\author{
Carlalberto RAVIZZA* - Gilles VINÇON** - Jean-Paul G. REDING***
}

\title{
The origins of the names of Plecoptera genera and species occurring in the Italian Region
}

\begin{abstract}
Riassunto: Origine dei nomi dei generi e delle specie di Plecotteri della Regione Italica.
Sono elencate le derivazioni dei nomi delle 177 specie di Plecotteri accertate in Italia. La maggior percentuale di nomi si riferisce a caratteristiche morfologiche della specie ( 56 specie), seguono quelli dedicati a stimati entomologi o a chi raccolse i primi esemplari (52 specie) e nomi riferiti a luoghi geografici o di derivazione etnologica (45 specie). Un numero limitato di specie (9) fa riferimento a peculiarità ecologiche, altre sono dedicate a un parente dell'autore (6) o anche a un artista o scienziato (3). Infine, 6 specie hanno un nome simbolico. Inoltre abbiamo compilato una particolareggiata bibliografia, elencando tutte le descrizioni originali di specie appartenenti alla plecotterofauna italiana.
\end{abstract}

\begin{abstract}
The origins of the names of the 177 species of stoneflies occurring in the Italian region are listed. These names chiefly refer to a taxonomic characteristic (56 species), then a dedication to a well-known entomologist or to the collector (52), then to either a geographical - ethnological (45) or to an ecological aspect (9). The remaining species are dedicated to someone in the author's family (6) or to an artist or scientist (3). Finally, 6 other species have a symbolic name. In addition, we also provide an exhaustive bibliography of the original species descriptions of the Italian Plecoptera fauna.
\end{abstract}

Key words: stoneflies, taxonomy, species name derivation, genus name derivation, Italy, Corsica, Sardinia, Sicily.

\section{INTRODUCTION}

Many times, considering the name of an insect species, one may wonder from where it had been derived or who was the person to whom it had been dedicated. Very often, though, names of both genera and species had been coined in a way that is not always understandable anymore to modern students, freed from the obligation to study Latin and Greek. Since the name of a species offers valuable hints and mnemotechnical clues that may shorten the identification process, we decided to summarize this kind of information on the etymology of the species names in this companion article to our study of the Italian stoneflies (Vinçon \& Ravizza, in preparation). In addition, we also provide an exhaustive bibliography of the original species descriptions of the Italian Plecoptera fauna.

Authors have had their own ways to name new species. Most of them chose a name related to some feature in morphology, body colour and flight period. Some others preferred a geographic name associated with the country of the species. There are also many species dedicated either to the person who had collected the first specimen, or to other naturalists, to honour their work, or in memoriam of some scientist of the past. When proposing a new name, some authors explained its etymology, while others did not provide such information, probably because they believed the name to be self-explanatory. After several decades or centuries, however, the original meaning of taxonomic names tends to fade away and fall into oblivion. Moreover, the origins of the older names of species and particularly of genera are often difficult to understand, because they refer to taxonomic problems of the $18^{\text {th }}$ and the $19^{\text {th }}$ century not shared by modern entomologists.

\section{NAMES OF THE Genera}

The names of the genera are listed according to the following systematic order of the families: Perlidae, Perlodidae, Chloroperlidae, Taeniopterygidae, Nemouridae, Leuctridae and Capniidae.

Perla Geoffroy, 1762. Properly speaking, Geoffroy did not coin the name Perla, but only restricted its scope to the order of the Plecoptera, mainly the large Perlidae, known at that time. The name Perla had been used already in the 17 th century to designate

\footnotetext{
${ }^{*}$ Carlalberto Ravizza, Largo O. Murani 4, 20133 Milano, Italy. E-mail: calbertoravizza@hotmail.it

${ }^{* *}$ Gilles Vinçon, Bd J. Vallier, 38100 Grenoble, France. E-mail: gvincon@gmail.com

${ }^{* * *}$ Jean-Paul G. Reding, Petit-Berne 2, CH-2035 Corcelles, Switzerland. E-mail: jean-paul.reding@bluewin.ch
} 
Anisoptera, and Pictet (1841: 5-6) attributes its coining to the pearl-like aspect of their eyes. In the 18th century, the name Perla then served to designate a variety of taxa belonging, from the present point of view, to different orders or infraorders: Anisoptera, Plecoptera and Trichoptera.

Dinocras Klapálek, 1907. From the Greek $\delta \varepsilon ı v o ́ \varsigma$ "terrible, terrifying" (changed to "dino", like in "Di-

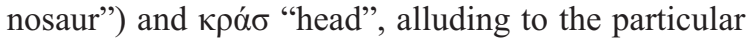
design of the cephalic mask of the genus.

Perlodes Banks, 1903. From the genus Perla and the Greek suffix "-ōdēs", meaning "having the aspect of". Perlodes is a replacement name created by Banks for the preoccupied Dictyopteryx of Pictet (1841).

Besdolus Ricker, 1952. From Russian: bez "without" and dolya "lobe", because the males of this genus lack the ventral lobe on the 7th sternite (Ricker 1976).

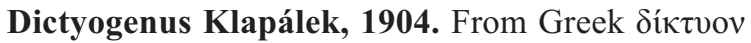
"net", referring to the reticulated aspect of the wing venation.

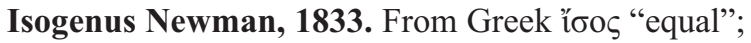
this new genus was created to set apart the Perlidae (of the British fauna) with brachypterous males (Dinocras cephalotes, Perla bipunctata (carlukiana)) from those where males and females were both macropterous, i. e. had the same lengths of wings in both sexes (Newman, 1836).

Isoperla Banks, 1906. From Greek î́os "equal". Isoperla had been coined by Banks in contrast to another (Nearctic) genus, namely Alloperla. Both names refer to details in wing venation. "I therefore do so, using the name Isoperla for those forms having the median vein extending basally parallel to the radius, and Alloperla for those forms having the median united to the radius at base." (p. 175)

Chloroperla Newman, 1836. From Greek $\chi \lambda \omega \rho$ ó $\varsigma$, meaning greenish-yellow, pale green, pale, (verdant) and the genus Perla.

Siphonoperla Zwick, 1967. From Greek oí $\varphi \omega v$ "small tube". This genus is named after the tubular or siphon-shaped male copulatory organ.
Xanthoperla Zwick, 1967. A compound word from

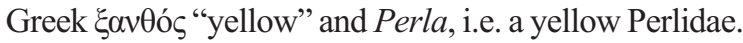

Brachyptera Newport, 1848. The first described species of this genus was Pictet's trifasciata the male of which is short-winged.

Rhabdiopteryx Klapálek, 1902. According to Klapálek himself, the name is composed of the Greek $\dot{\rho} \alpha \beta \delta$ íov "stripe" and $\pi \tau \dot{\varepsilon} \rho v \xi$ "wing". The name probably refers to the oblique dark stripes on the forewings.

Taeniopteryx Pictet, 1841. According to Pictet himself, the name is composed of the Greek tauvía "ribbon" and $\pi \tau \dot{\varepsilon} \rho v \xi$ "wing", referring probably to the grey bands crossing obliquely the forewings.

Nemoura Latreille, 1796. From the Latin nemo "none" and the Greek ov́pó "tail", to indicate that there are no caudal cerci in this genus, in contrast to what Latreille considers as Perla.

Protonemura Kempny, 1898. From Greek $\pi \rho \tilde{\tau} \tau ం \varsigma$ "first" and the genus Nemoura. This new genus is placed first in the family of the Nemouridae.

Amphinemura Ris, 1902. From Ancient Greek ỏ $\mu \varphi \hat{~}$ "around, on both sides of, all around, about" and Nemoura.

Nemurella Kempny, 1898. The genus Nemoura ( $\mathrm{Ne}$ mura) flanked by the Latin diminutive word-forming element -ella.

Leuctra Stephens, 1836. This genus name is somewhat enigmatic, and no explanation for its origin is offered. The name "Leuctra" is known only as a Greek place name, famous for the battle that took place there between the Thebans and the Spartans in 371 BC. The genus Leuctra had been coined by Stephens for the species Leuctra geniculata.

Tyrrhenoleuctra Consiglio, 1957. This name is composed of Tyrrhenian and Leuctra, to name a genus whose species only occur in the region of the Tyrrhenian Sea. Tyrrhenoleuctra is a replacement name for the preoccupied Strobliella, the latter named after the first collector (Strobl) by Klapálek 1901. 
Capnia Pictet, 1841. From the female of the Latin capnios, or Greek ká $t v 10 \varsigma$, which means "dark", an adjective used by Pliny to describe a very dark sort of grapes. The species described by Pictet (1841) under this new genus is Capnia (Perla) nigra, also pointing to the overall dark aspect of this taxon.

Capnioneura Ris, 1905, 1913. The wing venation of this genus resembles the one of the genus Capnia, whereas other aspects, notably its cerci, make it differ from it. From the genus Capnia and the Greek veṽpov "nervation, venation".

Capnopsis Morton, 1896. From Greek ö $\psi 1 \varsigma$ "resembling in appearance, alike or similar" and the genus Capnia. This genus was first described by Rostock (1892) under the genus Capnodes. Morton noted that this genus was preoccupied and proposed therefore the new genus replacement name Capnopsis.

Zwicknia Murányi, Gamboa \& Orci, 2014. These are the wordings of the original dedication: "The genus is dedicated to Prof. Peter Zwick, Schlitz, Germany, in recognition of his major contributions and establishing leadership in many fields of study of the Plecoptera. The name composed with the ending "nia" corresponding to Capnia; gender feminine."

\section{NAMES OF THE SPECIES}

abdominalis (Perla abdominalis Burmeister, 1839). From Latin abdomen, abdominis "abdomen, belly". The name refers to the characteristic orange colour of the abdomen.

albida (Leuctra albida Kempny, 1898). From Latin albidus "white, pale". The original description explains the name "albida" by the paler colour of the wings, as compared to other species of Leuctra (p. 13). algovia (Protonemura algovia Mendl, 1968). The first series of specimens was collected in the Allgäu in the south of Germany. Algovia corresponds to the Latin name of the German "Allgäu".

alpinum, alpina (Dictyogenus alpinum (Pictet, 1841); Rhabdiopteryx alpina Kühtreiber, 1934; Leuctra alpina Kühtreiber, 1934). From Latin alpina "inhabiting the Alps"; all three species are widespread in the Alps.

ameliae (Leuctra ameliae Vinçon \& Ravizza, 1996). It is dedicated to Amélia Vinçon, daughter of Gilles Vinçon. andreinii (Isoperla andreinii (Festa, 1938)). It was named in honour of Alfredo Andreini (1870-1943), a medical officer who was an amateur entomologist and a smart collector of insects, chiefly Coleoptera, both from Libya and from the northern Apennines.

annae (Leuctra annae Consiglio,1975). It was dedicated to Anne, the author's wife.

apenninicola (Leuctra apenninicola Ravizza, 1988). From the Latin suffix -cola "dwelling, cultivating" and Apennini "Apennines".

apicalis (Xanthoperla apicalis (Newman, 1836)). From Latin apicalis "apical". The origin of the name is unclear; the wording of the original description ( $\mathrm{p}$. 501) is as follows: Tota luteo-viridis, oculis antennarum apicibusque nigerrimis. "Entirely of a pale delicate green, with the eyes and extreme portions of the antennae intensely black." The epithet apicalis hence refers to the deeply black apical parts of the eyes and antennae.

archimedis (Leuctra archimedis Consiglio, 1968). This species, endemic to Sicily, was named in honour of the famous ancient scientist Archimedes (288 BC212 BC) who lived in Syracuse, a town in Sicily.

armata (Leuctra armata Kempny, 1899). From Latin armata "armed". The original description explains the name "armata" by the shield-like shape of the abdominal plate of male adults (p. 275).

auberti (Brachyptera auberti Consiglio, 1957; Protonemura auberti Illies, 1954; Leuctra auberti Ravizza \& Ravizza Dematteis, 1985). Species named in honour of the Swiss entomologist Jacques Aubert (1916-1995) author of more than one hundred papers on Plecoptera that contain the description of nearly 150 new species. Jacques Aubert undertook several collecting trips to Italy and described a great number of new species from this country. He was a curator and later the director of the Musée zoologique of Lausanne, and also professor of entomology in the Lausanne University and for many years, editor of the Mitteilungen der Schweizerischen entomologischen Gesellschaft.

aubertorum (Leuctra aubertorum Ravizza \& Ravizza Dematteis, 1994). In the last years of his life Aubert carried out researches on stoneflies on the Swiss Ticino Canton together with his wife Cécile and his firstborn son Charles-Edouard. Among the Plecoptera collected by them there was a single male of this species. "Aubertorum", genitive plural form, hence refers to the family of Jacques Aubert as a whole. 
ausonia (Protonemura ausonia Consiglio, 1955). From Latin Ausonia, i. e. the country of the Ausonii an autochthonous population inhabiting Southern Italy.

austriaca (Protonemura austriaca Theischinger, 1976). The type series was collected in the Austrian Alps.

autumnalis (Leuctra autumnalis Aubert, 1948). From Latin autumnalis "autumnal", referring to the flight period of this species.

biellensis (Leuctra biellensis Festa, 1942). The first collected specimens were from Biellese a Piedmont historic region at the far southern end of the Pennine Alps.

bipartita (Protonemura bipartita Consiglio, 1962). From Latin bipartitus "divided into two parts". The male has the styli separated from the subgenital plate in the paraprocts.

bipunctata (Perla bipunctata Pictet, 1833). From the prefix bi- "two, double" and punctatus "with dots". The name of this species, originally described from larval material, refers to the two round dark patches on both sides of the pronotum (Pictet 1833, p. 56; Pictet 1842, plate 11, fig. 1) of the larvae.

boreoni (Leuctra boreoni Aubert, 1962). It was discovered in the Boréon valley in the French Maritime Alps.

braueri (Leuctra braueri Kempny, 1898). Dedicated to the Austrian entomologist Friedrich Moritz Brauer (1832-1904) who was Professor of Zoology and Director of the Naturhistorisches Hofmuseum,Vienna; later he was appointed Professor of zoology in the University. He wrote many papers on Diptera and Neuroptera.

brevipennis (Leuctra brevipennis Ravizza, 1978). New adjective created from the Latin brevis "short" and penna "wing", referring to the shortwingedness in both sexes.

brevistyla (Protonemura brevistyla Ris, 1902). New adjective created from the Latin brevis "short" and stylus "style", referring to the very short style of this species compared to Protonemura nimborum or P. intricata.

bucolica (Protonemura bucolica Consiglio, 1957). From Greek ßоркодıкós "pastoral, shepherd's", or

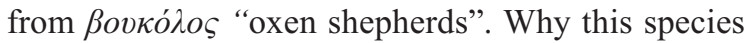
has this name is not explained by the author, but " $b u$ colica" seems to be a way to refer indirectly to Corsica, because this epithet is commonly associated with this island, where everything is "bucolic", from the trains to the hotels and the food. The association of Corsica with "bucolica" probably reaches back to Vergil's Bucolica.

budtzi (Leuctra budtzi Esben-Petersen, 1912). It was dedicated to Vilhelm Ferdinand Budtz (1855-1925), who collected in Corsica the first specimens of this species.

calabrica (Brachyptera calabrica Aubert, 1953). From Latin calabricus "from Calabria". This species inhabits Calabria, the far south region of the Italian peninsula.

canavensis (Leuctra canavensis Ravizza \& Ravizza Dematteis, 1992). This species is named after the Canavese (Canavesium in Latin), a historic region of Piemonte (Italy, Graian Alps). It is the only site in which this species has presently been found.

caprai (Leuctra caprai Festa, 1939; Protonemura caprai Aubert, 1954) Named in honour of the Italian entomologist Felice Capra (1896-1991), who was curator of the entomologic collections of the Natural History Museum of Genoa for about 35 years. Moreover for 30 years he was editor of the Società entomologica italiana reviews.

carbonaria (Isoperla carbonaria Aubert, 1953). From Latin carbonarius "related to charcoal", probably an allusion to the black abdomen of the adults of this species.

cephalotes (Dinocras cephalotes (Curtis, 1827)). From Greek $\kappa \varepsilon \varphi \alpha \lambda \eta$ "head". The species has a large and broad head.

cinerea selene (Nemoura cinerea selene Consiglio, 1959). In Greek mythology, Selene is the personification of divine order of the full Moon. The name probably refers to the main distinctive feature of this new subspecies: the head of the paraproct is half-moon shaped, which is not the case in the nominal species. cingulata (Leuctra cingulata Kempny, 1899). From Latin cingulatus "with a belt", because the abdomen of this species is provided with an arched, well pigmented band.

concii (Leuctra concii Consiglio, 1958). Species dedicated to Cesare Conci (1920-2011) who collected in Liguria the first specimens of this species. Conci was a specialist of Odonata, of which he published the first volume of the Fauna d'Italia, as well as Mallophaga and Homoptera Psylloidea. He was curator then director of the Natural History Museum of Milan. Moreover he was President of the Italian entomological Society for almost 30 years. 
consiglioi (Protonemura consiglioi Aubert, 1953). For more than 20 years Carlo Consiglio (born in 1929 at Rome) studied Odonata and particularly Plecoptera of which he described one new genus (Tyrrhenoleuctra) and 19 new species most of them endemic to Italy. At the University of Rome, he was at first professor of entomology, then full professor of zoology, devoted to nature conservation.

corsicana (Protonemura corsicana (Morton, 1930)). This species is endemic to Corsica.

costai (Protonemura costai Aubert, 1953; Leuctra costai Aubert, 1953). In honour of the Italian entomologist Achille Costa (1823-1898), who was professor of Zoology at the University of Naples. In his collections there were a few dry pinned specimens of these species.

cyrnea (Leuctra cyrnea Consiglio \& Giudicelli, 1965). From Latin Cyrnos after the Greek Kópvos "Corsica".

delmastroi (Leuctra delmastroi Vinçon, 2012). Dedicated to Giovanni Delmastro an Italian entomologist and hydrobiologist who collected many stoneflies in the western Italian Alps and Liguria.

dolasilla (Leuctra dolasilla Consiglio, 1955). This name derived from princess Dolasilla, tied to a cycle of legends from the region of the Dolomites, mountains from which the specimens belonging to the type series were collected.

dylani (Leuctra dylani Graf, 2007). In honor of Bob Dylan a poet and musician (Robert Allen Zimmerman) born in Duluth (Minnesota USA) in 1941, who was awarded the Nobel Prize in literature in 2016.

elisabethae (Protonemura elisabethae Ravizza, 1976; Leuctra elisabethae Ravizza, 1985). These species were dedicated by the author to his beloved wife Elisabetta Dematteis, partner in life and in collecting and studying Stoneflies. She was at first curator of the zoological museum then professor of zoology at the University of Milan.

ferreri (Dinocras ferreri (Pictet, 1841)). The author found two adult males of this species collected near Torino, in the collection donated by the canon Gian Battista Ferrero (1756-1836) to the Geneva museum. The species was dedicated to him in memoriam.

festai (Leuctra festai Aubert, 1954). Named in honour of the Italian amateur plecopterologist Aldo Festa (1914-2001) from Genoa. In his youth, F. Capra who was his mentor, directed him to study Plecoptera. He was a pioneer in Italy in this kind of studies and de- scribed five new species, all endemic to Italy, with all of them confirmed as new species by the British plecopterologist Martin Mosely.

flexuosa (Nemoura flexuosa Aubert, 1949). From the Latin flexuosus "bent"; refers to the slightly excised medial edge of the male paraprocts (Aubert, personal communication).

fochettii (Leuctra fochettii Vinçon \& Vitecek, 2017). Species named in honour of Romolo Fochetti, born in 1958 at Roma, for his contributions to the knowledge of the Italian Plecoptera. Fochetti is the co-author of the volume Plecoptera in the Fauna d'Italia series. At present he is a professor of zoology at Tuscia University (Viterbo).

fontium (Dictyogenus fontium (Ris, 1896)). From Latin fontium genitive plural of the Latin fons "spring", hence "of springs", since the species occurs at high altitude mainly in the headwaters of glaciers, brooks and rivulets.

fraterna (Leuctra fraterna Morton, 1930). From Latin fraterna "brotherly, fraternal". As to the name the author explains that the two paired parallel abdomen processes "have the apex shaped more like a bird's head, the beaks turned inwards and connected by a narrow, very slightly strip".

fulviceps (Nemoura fulviceps Klapálek, 1902). From Latin fulvus "fulvous" and ceps for caput "head". Fulvous-headed species, by the rear part of the light brown head.

fusca (Leuctra fusca (Linnaeus, 1758)). From Latin fusca "brown", probably referring to the brown colour of the body, which is, however, common to many other Leuctra species.

gardinii (Leuctra gardinii Ravizza, 2005). This wingless Leuctra was dedicated to the Italian entomologist Giulio Gardini from Genoa, who collected its first specimens. He is a specialist of Arachnida, Pseudoscorpionida.

gattolliati (Zwicknia gattolliati Vinçon \& Reding, 2018). Species dedicated to Jean-Luc Gattolliat, curator in the Musée cantonal de zoologie, Lausanne, who collaborated with the authors to recognize this new species.

geniculata (Leuctra geniculata Stephens, 1836). From Latin geniculatus "knotty", provided with knots, relating to the sclerotized processes protruding from the basal segments of nymphal antennae.

grammatica (Isoperla grammatica (Poda, 1761)). The creation of the species name Isoperla grammatica 
is traditionally attributed to Poda (1761, p. 99 , sub nom. Phryganea grammatica) and the city of Graz (Austria) recorded as its type locality, and not Greece, as some authors pretend, since the Latin Graecia refers to the Austrian city (Rupprecht 1984). The attribute grammatica, "lettered" "inscribed" refers to a letter « $\mathrm{V} »$ or $" \mathrm{C}$ » engraved on the frontoclypeus of the species and is supposed to correspond to the typical dark horse-shoe mark on the frons of Isoperla grammatica. The adjective "grammatica" refers to the Greek $\gamma \rho \alpha ́ \mu \mu \alpha$ "letter". Poda's original Latin description says: fronte $V$. vel C. nigro inscripta "a black letter $\mathrm{V}$ or C inscribed on the forehead".

grafi (Leuctra grafi Vinçon \& Vitecek, 2017). Species named in honour of Wolfram Graf for his contribution to the knowledge of the Austrian Stoneflies. Wolfram Graf is an aquatic biologist and entomologist who works mainly on Trichoptera, Plecoptera and other aquatic insects. He is professor of Hydrobiology at Vienna University.

grandis (Perla grandis Rambur, 1842). From Latin grandis "large", referring to the dimension of the species, the largest among all European Perlidae.

hamulata (Xanthoperla hamulata (Morton, 1930)). From Latin hamus "hook, hooked", from which the adjective hamulatus "with a hook" is derived, referring to the hook-shaped male epiproct. The original description by Morton says "Anal appendage seen from above dark brown at its base, the exposed part mostly pale".

handlirschi (Leuctra handlirschi Kempny, 1898). Species named in honour of the Austrian entomologist Anton Handlirsch (1865-1935). He studied Hymenoptera and Hemiptera and became director of the department of entomology of the Natural History Museum of Vienna.

harperi (Rhabdiopteryx harperi Vinçon \& Murányi, 2009). Dedicated to Pierre-Paul Harper (1942-2019), a Canadian entomologist who studies for many years the Plecoptera of Canada and other regions.

helenae (Protonemura helenae Nicolai, 1985). Dedicated to Helen, the author's wife.

helvetica (Leuctra helvetica Aubert, 1956). From Latin "helveticus", adjective derived from the Confoederatio Helvetica, the Helvetian Confederation, or Switzerland. The specimens of the type series of this species have been collected in the Swiss Central Alps. This species was first described by Aubert 1954a under the preoccupied name Leuctra variabilis. The
Latin name variabilis "variable" refers, according to Aubert, to the subtle morphological variations of this species, which has affinities with Leuctra niveola, $L$. prima and L. pseudosignifera .

hesperiae (Nemoura hesperiae Consiglio, 1960). From Greek E $\sigma \pi \varepsilon \rho i \alpha$, Latin Hesperia, the people of a western country, that is Italy.

hexacantha (Leuctra hexacantha Despax, 1940). From Greek "̌ $\xi$ "six" and ö $\alpha \nu v \alpha$ "thorn", "bearing six thorns", which refers to the three paired processes on the $6^{\text {th }}, 7^{\text {th }}$ and $8^{\text {th }}$ male abdomen terga.

hippopus (Leuctra hippopus Kempny, 1899). From Greek i $\pi \pi$ os "horse" and $\pi$ ov́ $\varsigma$ "foot", because the paired processes on the $8^{\text {th }}$ male tergum remind of a horse hoof.

hirpina (Protonemura hirpina Consiglio, 1958). From Latin Hirpini, an ancient Samnite people settled in Southern Italy.

hrabei (Protonemura hrabei Raušer, 1956). This species was dedicated to the Czechoslovakian entomologist Sergej Hrabe (1899-1984), an eminent specialist of subterranean and cavernicolous aquatic insects.

hyblaea (Isoperla hyblaea Consiglio, 1961). It is the Latin name of Megara Iblea, an ancient Greek colony sited near the present town of Augusta in Sicily and at present a mountain group.

ichnusae (Protonemura ichnusae (Consiglio, 1957)). From Greek 'I $\chi$ voṽ $\alpha \alpha$, one of the names which had been given to Sardinia by the ancient Greeks.

illiesi (Perla illiesi Braasch \& Joost, 1973; Nemoura illiesi Mendl, 1968). Named in honour of Joachim Illies (1925-1982), a German entomologist and hydrobiologist who published many papers on the Plecoptera of the world, including a world catalogue of the order. He was head of the Limnologische Flussstation Schlitz which he turned into a Mekka for students of Plecoptera.

illyrica (Isoperla illyrica Tabacaru, 1971). For the Romans, Illyria was the region corresponding to the western section of the Balkan Peninsula, towards the south-eastern coast of the Adriatic Sea, inhabited by the Illiri, an ancient Indo-European population.

ilvana (Isoperla ilvana Consiglio, 1958). This species is endemic to Elba (in Latin Ilva), the largest island of the Tuscan Archipelagos in the Tyrrhenian Sea.

incudensis (Leuctra incudensis Vinçon \& Ravizza, 2000). The species is named after the Incudine Mount in the south of Corsica where this species had been discovered. 
inermis (Leuctra inermis Kempny, 1899). From Latin inermis "unarmed", as the males of this species have no sclerified appendages on the abdominal tergites.

insubrica (Leuctra insubrica Aubert, 1949). Insubria is a historic region, corresponding to the territory sited between the Po River and the pre-alpine lakes, inhabited in the proto-historic period from the IV century $\mathrm{BC}$ by the Insubri.

insularis (Isoperla insularis (Morton, 1930)). From Latin insularis "belonging to an island". This species is endemic to Corsica and Sardinia islands.

intricatus, intricata (Perlodes intricatus (Pictet, 1841); Protonemura intricata Ris, 1902). From Latin intricatus "entangled, intricate, complex, complicated". In both species wings have a complicated vein net.

italica (Siphonoperla italica (Aubert, 1953); Protonemura italica Aubert, 1954). Both species are endemic to the Italian Region.

jahorinensis (Leuctra jahorinensis Kacanski, 1972). After the Jahorina Mountains in Bosnia, type locality of this species.

julia (Protonemura julia Nicolai, 1983). This species was discovered in the Julian Alps.

juliettae (Leuctra juliettae Vinçon \& Graf, 2011). This species occurs in the Pre-Alps close to Verona, so the authors dedicate it to the emblematic Verona lovers, Romeo and Juliette.

kir (Isoperla kir Fochetti \& Vinçon, 1993). Kir was the Phoenician name of Corsica, the island from which this species is endemic.

kühtreiberi (Taeniopteryx kühtreiberi Aubert, 1950). Dedicated to the Austrian plecopterologist Josef Kühtreiber (1908-1996), who was the author of an important monograph on the North Tirol Stoneflies.

lagrecai (Protonemura lagrecai Aubert, 1954). It was dedicated to Marcello La Greca (1914-2001) an Italian entomologist and biogeographer. He studied mainly Orthoptera and Mantodea and was a professor of compared anatomy and zoology, first at Naples then at Catania.

lateralis (Protonemura lateralis (Pictet, 1836)). From Latin lateralis "lateral", referring probably to the yellow pronotum margins.

leptogaster (Leuctra leptogaster Aubert, 1949). Derived from the Greek $\lambda \varepsilon \pi \tau$ ó $\varsigma$ "delicate", and $\gamma \alpha \sigma \tau \eta ́ \rho$ "stomach", for its thin and slender abdomen.

ligurica (Leuctra ligurica Aubert, 1962) From Latin ligurica, corresponding adjective to the Liguria, the region in which this apterous species is to be found. It lives in a restricted hilly area between the Alps and the Apennines.

lucana (Nemoura lucana Nicolai \& Fochetti, 1991). From Latin Lucania, a Southern region of Italy where this species had been discovered.

lugens (Isoperla lugens Klapálek, 1923). From Latin lugens "mourning, grieving, lamenting". This species has a dark appearance with blackish-brown cerci. macrura (Protonemura macrura Aubert, 1953). From the Greek words $\mu \alpha \kappa \rho o ́ \varsigma \varsigma$ "large", and ov́ṕ "tail". This species is characterized by the length of the cerci which look like a double tail.

major (Leuctra major Brinck, 1949). From Latin comparative major "larger", because it is larger compared to the other Leuctra species.

marginata (Perla marginata (Panzer, 1799); Nemoura marginata Pictet, 1836). From Latin marginata "with a well marked edge or margin". The epithet "marginata" is the most commonly used in botanical and zoological names, generally without any explicit information as to its derivation. Neither Pictet (1836) nor Panzer (1799) explain the reasons why they chose this epithet.

megacephala (Dinocras megacephala Klapálek, 1907). The name is derived from the Greek $\mu \varepsilon \gamma \alpha \varsigma$ "large" and $\kappa \varepsilon \varphi \alpha \lambda \eta$ "head" and refers to the wide head of this species.

mercuryi (Taeniopteryx mercuryi Fochetti \& Nicolai, 1996). This species has been dedicated to Freddie Mercury (1946-1991), the emblematic singer of the Queen, a Rock group.

meridionalis (Leuctra meridionalis Aubert, 1951). This species was described based on specimens collected in the Ticino Canton on the southern slopes of the Swiss Alps. From the Latin meridionalis "mid-day, when the sun is in the south".

meyeri (Protonemura meyeri (Pictet, 1841)). Dedicated to Rudolf Ludwig Meyer-Dür (1812-1885). He was a Swiss entomologist who specialized in Hemiptera, Orthoptera and Neuroptera. He was a founding Member of the Swiss Entomological Society (Société Entomologique Suisse).

microcephalus (Perlodes microcephalus (Pictet,

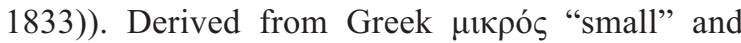
$\kappa \varepsilon \varphi \alpha \lambda \eta$ " "head". This species has a head that is smaller than the one of the related Perlodes intricatus.

minima (Nemoura minima Aubert, 1946). From the Latin minimus "smallest". It is the smallest species among the genus Nemoura. 
monilicornis (Brachyptera monilicornis (Pictet, 1841)). The antennal segments are rounded and well separated from each other, like beads. From Latin monile "neck-lace" and cornum "antenna".

montana (Siphonoperla montana (Pictet, 1841)). Latin montanus "mountainous". This species occurs in many types of watercourses in the Alps.

mortoni (Nemoura mortoni Ris, 1902; Leuctra mortoni Kempny, 1899). These species were dedicated to Kenneth J. Morton (1858-1940), a Scottish entomologist with a particular interest in the study of Odonata, Neuroptera and Plecoptera.

moselyi (Leuctra moselyi Morton, 1929). Species named in honour of the British entomologist Martin Ephraim Mosely (1867-1948). As an amateur he devoted much of his spare time to study Ephemeroptera, Plecoptera and chiefly Trichoptera, publishing over 100 scientific papers.

muranyii (Leuctra muranyii Vinçon \& Graf, 2011). Dedicated to the Hungarian entomologist Dávid Murányi. His publication list now includes many papers on Far Eastern fauna; he lived in Japan for over a year and travelled in China as well. He established the genus Zwicknia and described many stonefly species from eastern Europe and from the Oriental region.

nebulosa (Taeniopteryx nebulosa (Linnaeus, 1758)). From Latin nebulosus "misty"; to indicate the opaque wings with little marked veins.

neglecta (Rhabdiopteryx neglecta Albarda, 1889). From Latin neglectus (feminine neglecta) "disregarded, ignored, neglected". The species was neglected because confused with another species, namely Taeniopteryx nebulosa.

nemuroides (Capnioneura nemuroides Ris, 1905). The name reminds us of the feature of a Nemoura species, whereas its wing venation is close to that of Capnia.

nigra (Capnia nigra (Pictet, 1833)). From Latin niger "black" for the dark colour of this species.

nimborella (Protonemura nimborella Mosely, 1930). From Latin -ella, a diminutive word-forming element, so nimborella refers to a small-sized P. nimborum.

nimborum (Protonemura nimborum Ris, 1902). From the genitive plural of the Latin nimbus "cloud, or dark grey cloud that often produces rain or snow". The reason for this name is unclear. The name perhaps refers to the "cloudy" aspect of the wing venation. nitida (Protonemura nitida (Pictet, 1836)). From Latin nitidus "shining". The original description (p.
179) emphasises the shining (= nitidus) black head and pronotum, thought to be characteristic of the taxon. niveola (Leuctra niveola Schmid, 1947). The adjective niveola is not attested in classical Latin; it is, however, a common botanical epithet. By its etymology, the name is related to snow and hence points to the early flight period of this species which is often found walking on snow.

nubeculum (Isogenus nubeculum Newman, 1833). Nubeculum is a Latin expression of post-classical origin, used mainly in zoology to point to characteristics denoting a stained aspect. The term is related to the Latin nubes "cloud". The name refers to the cloudy stain on the wings distinctive of this genus.

obscura (Isoperla obscura (Zetterstedt, 1840)). From Latin obscurus "dark, shadowy, indistinct". The general colour of this species is dark-yellow, usually well pigmented.

obtusa (Nemoura obtusa Ris, 1902). From Latin $o b$ tusus "blunted, not sharp", referring to the blunt paraprocts of the male.

oenotriae (Isoperla oenotriae Consiglio, 1967).The Oenotrians were an ancient people of Greek origin who inhabited a territory from Paestum to southern Calabria in southern Italy.

orobica (Isoperla orobica Ravizza, 1975). The name derives from the Orobian Alps where the species was found.

oropensis (Nemoura oropensis Ravizza \& Ravizza Dematteis, 1980). This species occurs in the headwater of the Oropa stream, in the Biellese, an historic Piedmont region in the southern slopes of the Pennine Alps.

orsiera (Leuctra orsiera Ravizza \& Vinçon, 2003). By the Orsiera Mount near Susa, where was collected the type series of this species.

oxylepis (Isoperla oxylepis (Despax, 1936)). A compound word, from Greek o $\xi u ́ s ~ " s h a r p$, pungent, pointed" and $\lambda \varepsilon \pi i \varsigma$ "scale". Despax was the first who studied the penial armature of Isoperla, and felt this species had very sharp scales.

padana (Protonemura padana Vinçon \& Ravizza, 2005). From Latin Padanus derived from Padus, the Latin name of the Po River.

palliventris (Nemoura palliventris Aubert, 1953). Compound name from Latin pallidus "pale yellowgreen" and venter (genitive ventris) "belly" alluding to the pale abdomen of the adults.

pasquinii (Leuctra pasquinii Consiglio, 1958). The author has dedicated this species to Pasquale Pasquini 
(1901-1977), his Professor of zoology at the University of Rome, who granted financial support to researches on Plecoptera in Central Italy.

pesarinii (Nemoura pesarinii Ravizza \& Ravizza Dematteis, 1979). The first specimens of this species were collected by Carlo Pesarini (1946-2017), who was curator of invertebrate collections in the Natural history Museum of Milan and researcher of Coleoptera and Araneidae.

petricola (Capnioneura petricola Giudicelli, 1967). From Latin petra "rock" and the suffix -cola "dwelling, cultivating". The species inhabits temporary brooks drying out in summer; adult specimens were collected by the author under stones in December.

pictetii (Nemurella pictetii Klapálek, 1900). Named in honour of the Swiss zoologist and palaeontologist François-Jules Pictet (1809-1872) who was the first to publish in 1841 a very important handbook on Plecoptera containing the descriptions of a number of new species, and completed with a volume of Stonefly full colour paintings. He established the genera Taeniopteryx and Capnia.

praecox (Protonemura praecox (Morton, 1894)). From the Latin praecox "very early". The name refers to the emergence period of the species in early spring. prima (Leuctra prima Kempny, 1899). From Latin prima "first", as it is one of the first Leuctra emerging in winter, adults being found often on snow.

pseudorosinae (Leuctra pseudorosinae Aubert, 1954). Closely related to $L$. rosinae, with which it might be confused.

pusilla (Leuctra pusilla Krno, 1985). From Latin pusillus "tiny, little", probably because the size of the species is smaller than the average Leuctra size.

queyrassiana (Leuctra queyrassiana Ravizza \& Vinçon, 1991). It was named after the Queyras massif in the French Hautes Alpes.

rauscheri (Leuctra rauscheri Aubert, 1957). This species was named in honour of the Czech plecopterologist Jaroslav Raušer (1925-1993). By profession he was a geographer in the Prague University, but always loved to work on stoneflies publishing more than 20 papers.

ravizzai (Leuctra ravizzai Ravizza Dematteis \& Vinçon, 1994). Born in 1934 at Milan, he is an amateur entomologist, who for half a century dealt with European Stoneflies, mainly the ones occurring in the Italian Region.

ravizzarum (Besdolus ravizzarum Zwick \&
Weinzierl, 1995). The Ravizza couple collected a series of specimens that they classified as Dictyogenus ventralis, but it was a new species which was named in their honour.

risi (Brachyptera risi (Morton, 1896)). Friedrich Ris (1867-1931) was a Swiss entomologist who specialised in Odonata. He was Director of a psychiatric clinic in Rheinau, Switzerland.

rivorum (Nemoura rivorum Ravizza \& Ravizza Dematteis, 1995). From Latin genitive plural of rivus "brook, stream, streamlet".

rivulorum (Isoperla rivulorum (Pictet, 1841)). From Latin genitive plural of rivulus diminutive of rivus "a small brook, rivulet".

rosinae (Leuctra rosinae Kempny, 1900). Species dedicated to "Fräulein" (Miss) Rosine Handlirsch (1848-1938), a sister of Anton Handlirsch. She was an artist and poet, and one of the first feminists in 19th century Vienna. Rosine Handlirsch is probably also one of the first female plecopterologists, and Kempny had dedicated the species to her because she was its first collector.

ruffoi (Protonemura ruffoi Consiglio, 1961). Sandro Ruffo (1915-2010) was a zoologist and zoogeographer, in 1945 he became curator, in 1964 director of the Natural History Museum of Verona. He published more than 300 papers chiefly on Amphipods, of which he was a world specialist, and also on Coleoptera Chrysomelidae. It was co-editor of the Checklist and Distribution of the Italian Fauna too.

sabina (Nemoura sabina Fochetti \& Vinçon, 2009). Refers to the Latin name of the Region where it was collected in Latium.

saccai (Isoperla saccai (Festa, 1939)). Dedicated to Giuseppe Saccà (1916-2008) who first collected a couple of specimens of this species. Saccà, was a doctor of medicine, but his love of entomology led him professionally to work in applied entomology, focusing his scientific activity on disease vectors and their control, publishing 106 original papers dealing with Leishmania vectors, Anopheles mosquitoes and food pests.

salfii (Protonemura salfii Aubert, 1954). Dedicated to Mario Salfi (1900-1970), an Italian zoologist and entomologist. In 1948 he became professor of zoology at the University of Naples. His studies concerned mainly the taxonomy, biogeography and ecology of Orthoptera as well as Tunicata Ascidiacea.

schilleri (Capnopsis schilleri (Rostock, 1892)). The 
author dedicated this species to his friend Karl Schiller (1840-1910) who collected the first six adult specimens near Dresden in Germany.

schmidi (Leuctra schmidi Aubert, 1946). Species dedicated to the Swiss entomologist Fernand Schmid (1924-1998) who collected the first specimens of this species.

schoenemundi (Taeniopteryx schoenemundi (Mertens, 1923)). This species is dedicated to Eduard Schoenemund (1886-1943), an important German freshwater entomologist, who published 87 works, mainly on Mayflies, and 17 on Stoneflies.

sesvenna (Leuctra sesvenna Aubert, 1953). The specimens of the type series were collected in the Sesvenna Valley in Engadine (Rhaetian Alps, Switzerland).

seticornis (Brachyptera seticornis (Klapálek, 1902)). Name given in contradistinction to Pictet's Brachyptera monilicornis. The segments of the antennae of this new species do not have a bead-like aspect, like pearls in a necklace as we find it in B. monilicornis, but are more like bristles, as the original description says (p. 168). From Latin seta "hair, bristle" and cornum "antenna".

sicula (Protonemura sicula Consiglio, 1961). The name is derived from the latinized adjective for "Sicily" from where this species is endemic.

silana (Leuctra silana Aubert, 1953). The name derives from the Sila plateau in Calabria, where the species was found.

sinuata (Nemoura sinuata Ris, 1902). From the Latin sinuatus "bent". In lateral view the epiproct sclerite appears sinuate.

standfussi (Amphinemura standfussi Ris, 1902). This species was dedicated to Maximilian Rudolph Standfuss (1854-1917) a German-Swiss entomologist specialized in Lepidoptera.

stankovitchi (Taeniopteryx stankovitchi Ikonomov, 1978). Dedicated in memoriam of Professor Sinicha Stankovitch (1892-1974) who was an esteemed researcher of Limnology in Serbia.

subalpina (Leuctra subalpina Vinçon, Ravizza \& Aubert, 1995). The species name comes from Latin $s u b$ "under, beneath" and alpina, as this species generally occurs in the Alps at lower altitudes than the closely related L. alpina and inhabits mountainous regions at the foothills of the Alps (Jura, Northern Apennines).

sulcicollis (Amphinemura sulcicollis (Stephens, 1836)). From Latin sulcus "furrow, wrinkle" and col- lum "neck", supposed to be distinguished by a furrow on the pronotum.

susemicheli (Chloroperla susemicheli Zwick, 1967). Species dedicated to Georg Susemichel (1926-2007), first collector of the species. He assisted students of aquatic insects far beyond his obligations as a member of the technical staff of the Schlitz institute.

teriolensis (Leuctra teriolensis Kempny, 1900). This species was described from specimens collected in Tyrol/Tirolo in the Atesine Alps. The adjective teriolensis is a modern derivation from the place name of Tyrol.

triangularis (Amphinemura triangularis Ris, 1902). From Latin triangularis "triangular", an allusion to the shape of the epiproct, in dorsal view.

trifasciata (Brachyptera trifasciata (Pictet, 1832)). From the prefix tri- "three, thrice" and fasciatus "banded". The forewings of the females have three transverse pigmented stripes, while the male is short winged.

tripunctata (Chloroperla tripunctata (Scopoli, 1763)). From the prefix tri- "three, thrice" and punctatus "with dots". A reference to the three black ocelli on the pale head.

tyrrhena (Protonemura tyrrhena Festa, 1938). Named after a land area around the Tyrrhenian Sea (Corsica, Sardinia, and Italy's west coast). This species was described from specimens collected in localities belonging to the Tuscan Archipelagos.

uncinata (Nemoura uncinata Despax, 1934). From the Latin adjective uncinatus "possessing a hook" derived from uncinus "hook, barb", a reference to the hooked male cercus.

undulata (Nemoura undulata Ris, 1902). From Latin undulatus "wavy, undulated". The veins at the apex of the wings are sinuous (Aubert 1950b).

vesulensis (Leuctra vesulensis Ravizza \& Ravizza Dematteis, 1984). After the Latin name Mons Vesulus $=$ Viso Mount.

vidua (Capnia vidua vidua Klapálek, 1904). From Latin vidua "widow"; no males were initially collected.

vinconi (Leuctra vinconi Ravizza \& Ravizza Dematteis, 1993). Species dedicated to the French entomologist Gilles Vinçon, a keen student of Stoneflies, who collected the first specimens of this Leuctra, and recognized that it was a new species.

zavattarii (Tyrrhenoleuctra zavattarii (Consiglio, 1956)). Species dedicated to Edoardo Zavattari (1883- 
1972), who was a biologist, explorer, entomologist and zoogeographer. For many years he was professor of zoology and director of the Istituto di zoologia dell'Università di Roma,

zwicki (Leuctra zwicki Ravizza \& Vinçon, 1991; Isoperla zwicki Tierno de Figueroa \& Fochetti, 2001). Peter Zwick, born in 1941 at Berlin is a qualified entomologist who studies mainly Plecoptera. He was for more than 20 years editor of Aquatic Insects and director of the Limnologische Flussstation of Schlitz. He published the important textbook of the Plecoptera phylogenetic system and catalogue, and established the genera Siphonoperla and Xanthoperla.

\section{DisCUSSION}

According to the origin of their name, the Italian species can be subdivided into 7 groups.

\section{Names pointing to a morphological feature (56 species).}

Most of these names appear to be derived from Latin, only a few ones from ancient Greek

abdominalis, albida, apicalis, armata, bipartita, bipunctata, brevipennis, brevistyla, carbonaria, cephalotes, cingulata, flexuosa, fulviceps, fusca, geniculata, grammatica, grandis, hamulata, hexacantha, hippopus, inermis, intricata, intricatus, lateralis, leptogaster, lugens, macrura, major, marginata (2), megacephala, microcephalus, minima, monilicornis, nebulosa, neglecta, nemuroides, nigra, nimborella, nimborum, nitida, nubeculum, obscura, obtusa, oxylepis, palliventris, pseudorosinae, pusilla, seticornis, sinuata, sulcicollis, triangularis, trifasciata, tripunctata, uncinata, undulata.

Names dedicated to the first collector or to a wellknown entomologist or biologist (53 species).

Twenty-three species out of fifty-one, concerning species endemic to Italy, were dedicated to Italian scholars. Almost all the remaining ones were named either to European plecopterologists or entomologists, except for the one dedicated to a Canadian plecopterologist. andreinii, auberti (3), aubertorum, braueri, budtzi, caprai (2), concii, consiglioi, costai (2), delmastroi, ferreri, festai, fochettii, gardinii, gattolliati, grafi, handirschi, harperi, hrabei, illiesi (2), kühtreiberi, lagrecai, meyeri, mortoni (2), moselyi, muranyii, pasquinii, pesarinii, pictetii, rauscheri, ravizzai, ravizzarum, risi, rosinae, ruffoi, saccai, salfii, schilleri, schmidi, schoenemundi, standfussi, stankovitchi, susemicheli, vinconi, zavattarii, zwicki (2).

Names pointing to a geographical or ethnological aspect (45 species).

algovia, alpina (2), alpinum, apenninicola, ausonia, austriaca, biellensis, boreoni, calabrica, canavensis, corsicana, cyrnea, helvetica, hesperiae, hirpina, hyblaea, ichnusae, illyrica, ilvana, incudensis, insubrica, insularis, italica (2), jahorinensis, julia, kir, ligurica, lucana, meridionalis, oenotriae, orobica, oropensis, orsiera, padana, queyrassiana, sabina, sesvenna, sicula, silana, subalpina, teriolensis, tyrrhena, vesulensis.

Names pointing to an ecological characteristic ( 9 species):

autumnalis, fontium, montana, niveola, petricola, praecox, prima, rivorum, rivulorum.

Names dedicated to a family member (5 species): ameliae, annae, elisabethae (2), helenae.

Symbolic names (6 species):

bucolica, dolasilla, fraterna, juliettae, selene, vidua.

Names dedicated to an artist or scientist (3 species): archimedis, dylani, mercuryi.

\section{ACKNOWLEDGEMENTS}

We are very grateful and warmly thank our colleagues and friends Roberto Poggi and Peter Zwick, who helped us both for the correct interpretation of a few species names etymology, and for completing the biography of some naturalists and entomologists of the past. 


\section{REFERENCES}

Albarda H., 1889 - Note sur la Taeniopteryx nebulosa L. et la T. praetexta Burmeister, Annales de la Société Entomologique de Belgique 33: 51-65.

Aubert J., 1946 - Les Plécoptères de la Suisse romande. Bulletin de la Société entomologique suisse 20 (1): 7-128.

AuBert J., 1948 - Un plécoptère nouveau des Préalpes vaudoises: Leuctra autumnalis n. sp. Bulletin de la Société entomologique suisse 21 (3): 469-470.

AuBERT J., 1949 - Plécoptères helvétiques. Notes morphologiques et systématiques. Bulletin de la Société entomologique suisse 22 (2): 217-236.

Aubert J., 1950a - Note sur les Plécoptères européens du genre Taeniopteryx Pictet (Nephelopteryx Klapálek) et sur Capnia vidua Klapálek. Bulletin de la Société entomologique suisse 23 (3): 303-316.

Aubert J., 1950b - Nemoura undulata Ris, un Plécoptère mal connu des Alpes suisses. Bulletin de la Société entomologique suisse 23 (1): 65-66.

AUBERT J., 1951 - Leuctra meridionalis $n$. sp., un Plécoptère nouveau du versant sud des Alpes. Bulletin de la Société entomologique suisse 24 (2): 181-182.

Aubert J., 1953a - Contribution à l'étude des Plécoptères et des Ephéméroptères de la Calabre (Italie méridionale). Annuario del1'Istituto e museo di zoologia dell'Università di Napoli 5 (2): 1-35.

AuBert J., 1953b - Plécoptères européens nouveaux. Bulletin de la Société entomologique suisse 26 (1): 72-76.

AuBERT J., 1953c - Les Plécoptères de la collection A. Costa (Musée zoologique de Naples). Annuario dell'Istituto e Museo di zoologia dell'Università di Napoli 5 (1): 1-6.

Aubert J., 1954a - Contribution à l'étude du genre Leuctra STEPHENS et description de quelques espèces nouvelles de ce genre. Bulletin de la Société entomologique suisse 27 (2): 124-136.

AuBERT J., 1954b - Nouvelle contribution à l'étude des Plécoptères de Calabre (Italie méridionale. Annuario dell'Istituto e Museo di zoologia dell'Università di Napoli VI (6): 1-18.

Aubert J., 1954c - Note sur quelques Plécoptères du Piémont et de Ligurie avec la description de deux espèces nouvelles. Bollettino Società Entomologica Italiana 84: 107-113.

Aubert J., 1956 - Synonymie et homonymie de quelques Plécoptères. Bulletin de la Société entomologique suisse 29 (2): 214.

AUBERT J., 1957 - Les Leuctra du groupe de inermis Kempny et quelques espèces inermes isolées (Plécoptères Leuctridae). Bulletin de la Société entomologique suisse 30 (4): 285-312.

AuBERT J., 1962 - Quelques Leuctra nouvelles pour l'Europe (Plécoptères Leuctridae). Bulletin de la Société entomologique suisse (Lausanne) 35: 155-169.

Banks N., 1903 - New name for Dictyopteryx Pictet. Ent. News. (Lancaster, Pa.) 14: 241.

BANKs N., 1906 - On the perlid genus Chloroperla. - Ent. News (Lancaster, Pa.) 17: 174-175.

BraAsch D., Joost, W., 1973 - Perla illiesi n. sp. aus Bulgarien (Insecta, Plecoptera). Reichenbachia (Dresden) 14 (13): $101-106$. BrIncK, P., 1949 - Studies on Swedish Stoneflies (Plecoptera). Opuscula entomologica, Supplementum (Lund) 11: 1-250.

Burmeister H., 1838-1839 - Handbuch der Entomologie. Zweiter Band. Besondere Entomologie, Abteilung 2, 1.-2. Hälfte. Kaukerfe. Gymnognatha. Theod. Chr. Friedr. Enslin, Berlin, pp. 757-1050 (Plec.: 863-881).

Consiglio C., 1955 - Due Nuove specie dei Plecotteri Italiani. Bollettino della Società Entomologica Italiana 85 (5/6): 70-77.

Consiglio C., 1956 - Note sul genere Strobliella Klapálek (Plecoptera). Memorie Società Entomologica Italiana (Genova) 35: 81-91.

Consiglio C., 1957a - Contributo alla conoscenza dei Plecotteri di Sardegna. Memorie Società Entomologica Italiana 36: 31-44.

Consiglio C., 1957b - Contributo alla conoscenza dei Plecotteri di Corsica. Memorie Società Entomologica Italiana 36: 121-135.

Consiglio C., 1957c - Tyrrhenoleuctra nomen novum. Bollettino della Società Entomologica Italiana 87 (1/2): 1.

Consiglio C., 1958a - Contributo alla conoscenza dei Plecotteri dell'isola d'Elba. Rivista di biologia 50 (1): 37-41.

Consiglio C., 1958b - Plecotteri dei Monti Picentini. Memorie Museo Civico Storia Naturale - Verona VI: 327-331.

Consiglio C., 1958c - Contributo alla conoscenza dei Plecotteri olognati dell'Italia centrale. Memorie Società Entomologica Italiana 37: 117-131.

Consiglio C., 1959 - Una nuova sottospecie di Nemoura cinerea Retzius (Plecoptera). Bulletin de Société entomologique suisse $32(2 / 3): 323-327$.

Consiglio C., 1960 - Fauna di Romagna (Collezione Zangheri) - Plecotteri. Memorie della Società Entomologica Italiana 39: 3639,1 plate.

Consiglio C., 1961a - Plecotteri di Sicilia e d'Aspromonte e classificazione delle Isoperla Europee. Memorie Museo Civico Storia Naturale, Verona, 9: 173-196.

Consiglio C., 1961 b - Attuali conoscenze sui Plecotteri di Sicilia. Archivio Botanico Biogeografico Italiano, Forlì, 37: 3-4.

Consiglio C.. 1962 - Un nuovo Plecottero del Monte Baldo. Memorie Museo Civico di Storia Naturale Verona X: 10: 101-104. 
Consiglio C., 1967a - Phryganea maxima Scopoli, 1763 (Insecta, Plecoptera): proposed suppression under the plenary powers. Bull. zool. Nomencl. (London) 24 4:246-247.

Consiglio C., 1967 b - Una nuova specie italiana e considerazioni sui gruppi di specie nel genere Isoperla (Plecoptera, Perlodidae). Fragmenta entomologica (Roma) 5, 1: 67-75.

Consiglio C., 1968 - Secondo contributo alla conoscenza dei Plecotteri di Sicilia. Fragmenta Entomologica (Roma) 6 (1): $45-61$.

Consiglio C., 1975 - Second contribution to the knowledge of Sardinian Plecoptera. Fragmenta Entomologica (Roma) 11 (1): 83-102.

Consiglio C., Giudicelli J., 1965 - Un nuovo Plecottero di Corsica. Bollettino Società Entomologica Italiana 95 (5/6): 94-96.

Consiglio C., Giudicelli J., 1966 - La $q$ di Leuctra cyrnea. Bollettino Società Entomologica Italiana 97 (1/1): 94-96.

CURTIS J., 1827 - British entomology; being illustrations and descriptions of the genera of insects found in Great Britain and Ireland: containing coloured figures from nature of the most rare and beautiful species, and in many instances of the plants upon which they are found. Vol. IV. Printed for the author, Londres, 194 species.

DESPAX R., 1934 - Plécoptères pyrénéens VIII. Étude et description de quelques formes de Nemoures apparentées à Nemura marginata (Pict.) Klap.. Bulletin de la Société d'Histoire Naturelle de Toulouse 66 (2): 255-270.

DespaX R., 1936 - Contribution à l'étude du genre Chloroperla (Pictet) (Isoperla Banks). Bulletin de la Société d'Histoire Naturelle de Toulouse 69 (3): 337-398.

DespaX, R., 1940 - Plécoptères de la Grande Chartreuse. Bulletin de la Société d'Histoire Naturelle de Toulouse, 75: $296-299$.

ESBEN-PETERSEN P., 1912 - Plecoptera. Addition to the knowledge of the neuropterous insect fauna of Corsica. Ent. Meddel. (Copenhagen) (2) 4: 352-353.

FestA A., 1938 - Studi sui Plecotteri italiani - II. Bollettino Società Entomologica Italiana 70: 29-32.

FESTA A., 1938 - Studi sui Plecotteri italiani - III. Note sulle Famiglie Leuctridae e Nemouridae. Bollettino Società Entomologica Italiana 70: 156-159.

Festa A., 1939 - Studi sui Plecotteri italiani - IV. Una nuova specie del genere Leuctra Stephens. Bollettino Società Entomologica Italiana 71: 23-25

Festa A., 1939 - Studi sui Plecotteri italiani - V. Una nuova specie del genere Leuctra Stephens. Bollettino Società Entomologica Italiana 71: 143-146.

Festa A., 1942 - Studi sui Plecotteri italiani - VI. Plecotteri raccolti dal Dott. Felice Capra in Val Chiobbia. Bollettino Società Entomologica Italiana 74: 61-63.

Fochetti, R., Nicolai P., 1996 - The genus Taeniopteryx in Italy: biochemical and morphological data with the description of Taeniopteryx mercuryi n. sp. (Plecoptera: Taeniopterygidae). Bulletin de la Société entomologique suisse 69: 95-106.

Fochetti R., VinçON G., 1993 - Un nouveau Plécoptère de Corse: Isoperla kir n. sp. (Plecoptera, Perlodidae]. Nouvelle Revue d'Entomologie (N.S.) 10 (4): 375-379.

Fochetti R., VinçON G., 2009 - A new species of Nemoura (Plecoptera: Nemouridae) from Central Italy, in: Zootaxa 2216 (1): 64-68.

Geofrroy E. L., 1762 - Histoire abrégée des insectes qui se trouvent aux environs de Paris ; dans laquelle ces animaux sont rangés suivant un ordre méthodique. Vol. 2. Durand, Paris. 690 pp.

GiUdicelli J., 1967 - Capnioneura petricola n. sp., Plécoptère nouveau de Corse. Annales de Limnologie 3 (2): 249 -266.

GRAF W., 2007 - Leuctra dylani sp. n. (Plecoptera: Leuctridae) from Italy. Aquatic Insects, 29 (1): 17-20.

IKonomov P., 1978 - Nouvelles espèces de Plécoptères (Insecta: Plecoptera) de Macédoine. Fragmenta Balcanica (Skopje) 10: 8397, No. 11: 231.

ILlies J., 1952 - Die europäischen Arten der Plecopterengattung Isoperla Banks (= Chloroperla Pictet) (Mit einem Beitrag zur Analyse der Verbreitungsgeschichte einer fließwasser-bewohnenden Gattung). Beiträge zur Entomologie 2 (4/5): 369-424.

Illies J., 1954 - Protonemura fumosa Ris 1902 und Pr. auberti n. spec. (Plecoptera). Zoologischer Anzeiger 152: 235-239.

Illies J., 1966 - Katalog der rezenten Plecoptera. R. Friedländer, Berlin. XXX, 631 pp. (Das Tierreich: eine Zusammenstellung und Kennzeichnung der rezenten Tierformen v 82).

JACOBSON G. G., BIANCHI V. L., 1905 - [1902-1905] Priamokriliya i Lozhnoschatokriliya Rossiyskoy Imperii i sopredelnikh stran [Insectes Orthoptéroïdes et Pseudonévroptéroïdes de l'Empire russe et de ses pays limitrophes], Izdanie A. F. Devriena, Saint-Pétersbourg 952 pp.

KAĆANSKI D., 1972 - Leuctra signifera jahorinensis n. ssp., eine neue Plecopteren-subspecies aus Jugoslawien. Bulletin de la Société entomologique suisse 45 (1-2): 37-41.

KEMPNY P., 1898 - Zur Kenntniss der Plecopteren. I. Über Nemura Latr. Verhandlungen der Zoologisch-Botanischen Gesellschaft in Wien 48: 37-68, Taf. I (1 planche, 14 fig.). 
KEMPNY P., 1898 - Zur Kenntniss der Plecopteren. II. Neue und ungenügend bekannte Leuctra-Arten. I. Theil. Verhandlungen der Zoologisch-Botanischen Gesellschaft in Wien 48: 213-221, Taf. III (1 plate, 16 fig.).

KEMPNY P., 1899 - Zur Kenntniss der Plecopteren. II. Neue und ungenügend bekannte Leuctra-Arten. II. Theil. Verhandlungen der Zoologisch-Botanischen Gesellschaft in Wien 49: 9-15, Taf. I (1 plate, 15 fig.).

KEMPNY P., 1899 - Zur Kenntniss der Plecopteren. II. Neue und ungenügend bekannte Leuctra-Arten. III. Theil (Schluss). Verhandlungen der Zoologisch-Botanischen Gesellschaft in Wien 49: 269-278, Taf. VI (1 plate, 16 fig.).

KEMPNy P., 1900 - Beitrag zur Perliden- und Trichopteren-Fauna Südtirols. Verhandlungen der Zoologisch-Botanischen Gesellschaft in Wien 50: 254-258.

KLAPÁLEK F., 1900 - Plecopterologické studie. Rozpravy Ceské Akad. (Praha) (2) 920: 1-34.

KLAPÁLEK F. 1901 - O nových a málo známých druzích palaearktických Neuropteroid. Věstník České akademie císaře Františka Josefa 10: 1-19.

KLAPÁLEK F., 1902a - Zur Kenntnis der Neuropteroiden von Ungarn, Bosnien und Herzegovina. Természetrajzi Füzetek kiadja a Magyar nemzeti Muzeum 25: 161-180.

KLAPÁleK F., 1902 b - Tres pérlidos de España. Boletín de la Sociedad Española de Historia Natural 2: 111-115.

KLAPÁLEK F., 1904a - Zpráva o výsledcích cesty do Transsylvanských Alp a Vysokých Tater. Věstník České Akademie císaře Františka Josefa pro vědy, Slovesnost a Umění 11: 719-730.

KLAPÁLEK F., 1904b - Über die europäischen Arten der Fam. Dictyopterygidae. Bulletin International de l'Académie des Sciences de Bohême (Sci. math.-nat.) 9: 1-10.

KLAPÁLEK F., 1907 - Die europäischen Arten der Gattung Perla Geoffr. - Bull. internat. Acad. Sci. Bohême (Sci. math.-nat.) (Praha) 12: 117-138.

KLAPÁLEK F., 1912 - Plécoptères. I. Fam. Perlodidae: monographische Revision, in: Collections zoologiques du baron Edm. de Selys Longchamps, Catalogue systématique et descriptif 4 (1): 1-66; fig. 1-58.

KLAPÁLEK F., 1923a - Plécoptères. II. Fam. Perlidae, subfam. Perlinae: monographische Revision, in: Collections zoologiques du baron Edm. de Selys Longchamps, Catalogue systématique et descriptif 4 (2): 1-120 ; fig. 1-85.

KLAPÁLEK F., 1923b - Plécoptères nouveaux. Annales de la Société Entomologique de Belgique 63: 21-29.

KRNO I., 1985 - Leuctra pusilla n. sp. (Plecoptera) from Slovakia. Biologia (Bratislava) 40: 1045-1048.

KÜHTREIBER J., 1934 - Die Plekopterenfauna Nordtirols. Berichte des naturwissenschaftlich-medizinischen Vereins, Innsbruck 43/44: I-VII; 1-219.

LAtreille P.A., 1796. (“an 5 de la République”): Névroptères. In: Précis des caractères génériques des insectes, disposés dans un ordre naturel: 96-104. Brive, Bordeaux.

LINNAEUS C., 1758 - Systema natura per regna tria naturae secundum classes, ordines, genera, species, cum characteribus, differentiis, synonymis, locis. Editio decima, reformata. Vol. 1. Impensis Direct. Laurentii Salvii, Holmiae (Stockholm), $823 \mathrm{pp}$.

MENDL H., 1968 - Plecopteren aus Österreich (Insecta - Plecoptera). Ein Beitrag zur Kenntnis der Plecopteren-Fauna Österreichs. Gewässer und Abwässer 47: 61-73.

MendL H., 1968 - Eine neue Plecoptere aus den Allgäuer Alpen. Bulletin de la Société entomologique suisse 40, 3/4: $249-252$.

Mertens H., 1923 - Biologische und morphologische Untersuchungen an Plekopteren. Arch. Naturgesch. (Berlin) (A) 89 2: 1-38.

Morton K. J., 1894 - Palaearctic Nemourae. Transactions of the Royal Entomological Society of London 42: 557-574, Plates XIII et XIV.

Morton K. J., 1896 - New and little-known Palaearctic Perlidæ. Transactions Royal Entomological Society of London 44: 55-63, Plate II.

Morton K. J., 1929 - Notes on the genus Leuctra with descriptions of two new species, and on the genus Capnia including a species new to the British fauna. Entomologist's rnonthly Magazine (London) 65: 128-134.

Morton K. J., 1930 - Plecoptera collected in Corsica by Mr. Martin E. Mosely. Entomologist's rnonthly Magazine (London), 66: 75-81.

Mosely M. E., 1930 - New European Trichoptera and Plecoptera. Transactions of the Entomological Society of London 78 (2): 237-254, pl. XIV.

Mosely M. E., 1932 - A revision of the European species of the genus Leuctra (Plecoptera). Annals and magazine of natural history: including zoology, botany, and geology: Series 10, vol. 10 (55): 1-41.

MurÁnyi D., GAMBoA M., Orci K. M., 2014 - Zwicknia gen. n., a new genus for the Capnia bifrons species group, with descriptions of three new species based on morphology, drumming signals and molecular genetics, and a synopsis of the West Palaearctic and Nearctic genera of Capniidae (Plecoptera). Zootaxa 3812 (1): 1-82.

Newman E., 1833 - Isogenus Entomological notes, Ent. Mag. (London) 1: 415.

Newman E., 1836 - Entomological notes. Ent. Mag. (London) 3: 499-501. 
NewPort C., 1848/1849 - Postscript to Mr. Newports Paper on Pteronarcys regalis. Proc. Linn. Soc. London, (1838-1848):387389 (fide Kimmins 1970: 360, pp. 387 and 388 were published in 1848, and p. 389 in 1849. The genus name Brachyptera is introduced on p. 388).

NiCOLAI P., 1983a - Contributo alla conoscenza dei Plecotteri del Friuli-Venezia Giulia (Plecoptera). Gortania Atti Museo Friulano Storia Naturale 4: 153-162.

Nicolai P., 1983b - A new species of Protonemura from the Italian Julian Alps (Plecoptera, Nemouridae). Aquatic Insects: International Journal of Freshwater Entomology 5 (3): 173-176.

Nicolai P., 1985 - On the evolution and biogeography of the Protonemura species of the corsicana Group, with the Description of $P$. helenae sp. n. from Sicily (Plecoptera, Nemouridae). Aquatic Insects (Lisse) 7 (4): 249-257.

Nicolai P., Fochetti R., 1991 - Nemoura lucana, a new species from the Italian southern Apennine (Plecoptera, Nemouridae). Aquatic Insects (Lisse) 13 (4): 245-249.

Olivier G. A., 1811 - Encyclopédie méthodique. Histoire naturelle. Insectes. Vol. 8. Panckoucke, Paris. 722 pp.

PAnZer G. W. F., 1799 - Fauna insectorum Germanicae initia oder Deutschlands Insecten. Vol. 12, Heft 71, p. $3+1$ plate. Felseckerschen Buchhandlung, Nuremberg.

Pictet F.-J., 1832 - Mémoire sur les larves de Némoures. Annales des sciences naturelles 26: 369-391. (pl. XIV: 13 fig. ; pl. XV: 10 fig.)

Pictet F.-J., 1833 - Mémoire sur les métamorphoses des Perles. Annales des sciences naturelles 28: 44-65. (pl. V: 14 fig. ; pl. VI: 13 fig.)

Pictet F.-J., 1836 - Description de quelques nouvelles espèces d'insectes du bassin du Léman. Mémoires de la société de physique et d'histoire naturelle de Genève 7 (1/2): 173-190, 1 pl.

PiCTET F.-J., 1841-1842 - Histoire naturelle générale et particulière des insectes névroptères: première monographie: familles des Perlides. J. Kessmann, Genève; J. B. Baillière, Paris. 2 vols (Vol. 1 : text, 423 pp. [publ. 1841]; Vol. 2 : 53 plates, Cherbuliez, Genève [publ. 1842]).

Poda von NeuHaus N., 1761 - Insecta musei Graecensis, quae in ordines, genera et species juxta Systema Naturae Caroli Linnaei digessit. Ex typis haeredum Widmanstadii, Graz. 139 pp. 1-127.

RAMBUR J. P., 1842 - Tribu des Perlides. In: Histoire naturelle des insectes: Névroptères: ouvrage accompagné de planches. Librairie encyclopédique de Roret, Paris. XVIII, 534 pp., 12 f. de pl.

RAuser, J., 1956 - Zur Kenntnis der Plecopterenfauna der mittleren Moravice. Acta Soc. zool. bohemoslov. (Prague) 20: 110-142.

RavizZa C., 1975 - Faunistica, ecologia e fenologia immaginale dei Plecotteri reofili nella val Brembana. Con descrizione di una specie nuova (Plecoptera). Redia, 56: 271-373.

Ravizza C., 1976 - Una specie nuova di Nemouridae dell'Appennino settentrionale (Plecoptera). Fragmenta Entomologica, 12: 127-132.

RaVIzZA C., 1978 - Una specie nuova di Plecottero dei monti del Biellese: Leuctra brevipennis n. SP. (Plecoptera Leuctridae). Redia, 61: 251-257.

RaVIzZA C., 1985 - Una specie nuova di Leuctridae della regione italica: Leuctra elisabethae n. sp. (Plecoptera). Atti della Società italiana di Scienze naturali e Museo civico di Storia naturale Milano, 126: 63-69.

RaVIzZA C., 1988 - Leuctra apenninicola, a new species of Stonefly (Plecoptera: Leuctridae) from the Apennines (Italy). Aquatic Insects, 10: 69-72.

RAVIZZA C., 2005 - Leuctra gardinii an apterous new species of Leuctridae (Plecoptera) from the Western Italian Alps. Aquatic Insects, 27: 95-97.

Ravizza C., Ravizza Dematteis E., 1979 - Un nuovo Plecottero delle Alpi Pennine: Nemoura pesarinii n. sp. (Plecoptera Nemouridae). Atti Società italiana Scienze naturali Museo civico Storia naturale Milano, 120: 3-10.

Ravizza C., Ravizza Dematteis E., 1980 - Nemoura oropensis n. sp., endemica dei monti del Biellese (Alpi Pennine). Natura, 71: 92-100.

Ravizza C., Ravizza Dematteis E., 1984 - Leuctra vesulensis, new species from the Western Italian Alps (Plecoptera: Leuctridae). Aquatic Insects, 6: 41-44.

Ravizza C., Ravizza Dematteis E. 1985 - Une nouvelle espèce de Leuctridae des Alpes Pennines : Leuctra auberti n. sp. (Plecoptera). Bulletin Société entomologique suisse 58 (1/4): 405-408.

Ravizza C., Ravizza Dematteis E., 1992 - Leuctra canavensis, a short winged new species of stonefly (Plecoptera: Leuctridae) from the Graian Alps (Italy). Aquatic Insects, 14: 93-96.

Ravizza C., Ravizza Dematteis E., 1993 - Leuctra vinconi a new species of stonefly (Plecoptera: Leuctridae) from the Pennine Alps Italy). Aquatic Insects, 15: 41-44.

Ravizza C., Ravizza Dematteis E., 1994 - Leuctra vinconi subspecies aubertorum, a new race of Leuctra from the Ticino Canton, Switzerland (Plecoptera Leuctridae). Bulletin Société entomologique suisse, 67: 37-41. 
Ravizza C., Ravizza Dematteis E., 1995 - Nemoura rivorum, a new species of Stonefly from the Northern Apennines (Plecoptera, Nemouridae). Bulletin de la Société entomologique suisse,68: 153-158.

RavizZa C., Vinçon G., 1991 - Une nouvelle espèce de Plécoptère des Préalpes françaises: Leuctra zwicki (Plecoptera, Leuctridae). Nouvelle Revue d'Entomologie 8 (1): 61-65.

RavizZa C., VinçON G., 1991 - Leuctra queyrassiana sp. n., a strongly orophilic stonefly (Plecoptera: Leuctridae) from the French Alps. Aquatic Insects, 13: 251-255.

RAVIzZA C., VINÇON G., 2003 - Leuctra queyrassiana orsiera, a new subspecies of Leuctra from the Cottian Alps, Italy (Plecoptera Leuctridae). Bollettino Società entomologica italiana, 135 (1): 19-23.

RAVIZZA C., VINÇON G., (in preparation) - An annotated checklist of the Italian stonefly fauna (Insecta: Plecoptera)

Ravizza Dematteis E., Vinçon G., 1994 - Leuctra ravizzai, an orophilic new species of Leuctra from the Western Alps (Plecoptera). Aquatic Insects 16 (2): 91-94.

RicKer W.E., 1952 - Systematic Studies in Plecoptera. Indiana Univ. Publ. Sci. Ser. 18: 200 pp.

RICKER W.E., 1976 - Origin of stonefly names proposed by Ricker and collaborators. Perla, Newsletter and Bibliography of the International Society of Plecopterologists 2: 5-19.

Ris F., 1896 - Die schweizer. Arten der Perlidengattung Dictyopteryx. Bulletin de la Société entomologique suisse 9 (7): $303-313$.

Ris F., 1902 - Die schweizerischen Arten der Perliden-Gattung Nemura. Bulletin de la Société entomologique suisse 10 (9): 378 405, +6 plates, pp. 432.

Ris F., 1905 - Zwei Notizen über schweizerische Perliden. Bulletin de la Société entomologique suisse 11 (2): 93-97.

Ris F., 1913 - Nochmals die Perlide Capnioneura nemuroides Ris und einige Bemerkungen zur Morphologie der Perliden. Entomologische Mitteilungen 2 (6): 178-185.

Rostock M., 1892 - Capnodes schilleri, eine neue deutsche Perlide. Berliner Entomologische Zeitschrift 37 (1), 1-6+ 1 plate.

Rupprecht R., 1984 - Isoperla grammatica Poda, 1761. Beschreibung eines Neotypus (Plecoptera). Annales de Limnologie 20 (1/2): 81-90.

SCHMID F., 1947 - Leuctra niveola n. sp. et quelques Plécoptères printaniers des Alpes suisses, in: Bulletin de la Société entomologique suisse 20 (7): 683-685.

Scopoli J.A., 1763 - Entomologia Carniolica exhibens insecta Carnioliae indigena et distributa in ordines, genera, species, varietates, methodo Linneana: 265-270. Ioannis Thomae Trattner, Vindobonae (Vienne). $420 \mathrm{col}$.

STEPHENS J.F., 1835-1837 - Illustrations of British Entomology or a Synopsis of Indigenous Insects: Containing their Generic and Specific Distinctions; with an Account of their Metamorphoses, Times of Appearance, Localities, Food, and Economy, as far as Practicable. Mandibulata, Vol. VI. Baldwin and Cradock, London, 240 pp. [Plecoptera, pp. 134-145, 1836].

TABACARU I., 1971 - Une nouvelle espèce du genre Isoperla (Plecoptera, Perlodidae) de Yougoslavie. Fragmenta Balcanica Musei Macedonici Scientiarum 8 (2): 9-15.

Theischinger G., 1975 - [publ. 1976]) Plecoptera (Insecta) aus Oberösterreich, IV. Protonemura austriaca spec. nov. Naturkundliches Jahrbuch der Stadt Linz 21: 135-141.

Tierno de Figueroa J.M., Fochetti R., 2001 - Isoperla zwicki sp. n. (Plecoptera, Perlodidae), a new Italian stonefly species. Revue suisse de zoologie; Annales de la Société zoologique suisse et du Muséum d'histoire naturelle de Genève 108(3): 483-486.

VINÇON G., 2012 - Leuctra delmastroi sp. n., a new Alpine species, with comments on the micro-endemism in the Leuctra genus in the southwestern Alps. Bulletin de la Société entomologique suisse 85: 201-208.

Vinçon G., Boumans L. P. C., Gattolliat J.-L., 2018 - Reinstatement of Leuctra biellensis Festa, 1942 (Plecoptera, Leuctridae). Alpine Entomology 2 (1): 35-43.

VInçOn G., Graf W., 2011 - Two new Alpine Leuctra in the L. braueri species group (Plecoptera, Leuctridae). Illiesia 7 (9): 92-103.

VinÇON G., MuRÁNYI D., 2009 - Revision of the Rhabdiopteryx neglecta species group (Plecoptera: Taeniopterygidae), Aquatic Insects: International Journal of Freshwater Entomology 31 (1): 203-218.

Vinçon G., RavizZa C., 1996 - Two new Leuctra in the inermis group: L. garumna from the Pyrenees and L. ameliae from the Western Alps (Insecta Plecoptera). Aquatic Insects, 18: 149-156.

VInÇON G., RAVIZZA C., 2000 - Leuctra cyrnea subsp. incudensis, an orophilic new race of Leuctra from. Southern Corsica (Insecta, Plecoptera). Atti Società italiana di Scienze naturali e Museo civico di Storia naturale Milano, 140: 107-110.

Vinçon G., Ravizza C., 2005 - A review of the French Protonemura (Plecoptera, Nemouridae). Annales de Limnologie 41 (2): 99-126.

Vinçon G., Ravizza C., Aubert J., 1995 - Leuctra subalpina, a new species of Leuctridae (Insecta, Plecoptera) from the Western Alps and the Apennines. Aquatic Insects: International Journal of Freshwater Entomology 17 (3): 181-186.

VINÇON G., REDING J.-P.G., 2018 - Zwicknia gattolliati, a new species of stonefly from Italy (Plecoptera: Capniidae). Zootaxa 4486 (1): 57-66. 
Vitecek S., Vinçon G., Graf W., Pauls S. U., 2017 - High cryptic diversity in aquatic insects: an integrative approach to study the enigmatic Leuctra inermis species group (Plecoptera). Arthropod Systematics and Phylogeny 75(3): 497-521.

ZETTERSTEDT J. W., 1840 - Insecta Lapponica. L. Voss, Leipzig. 1140 cols.

Zwick P., 1967 - Revision der Gattung Chloroperla Newmann (Plecoptera). Bulletin de la Société entomologique suisse 40 (1/2): $1-26$.

ZWICK P., 1970 - Was ist Nemoura marginata F.J. Pictet 1836 ? Bestimmung eines Neotypus und Beschreibung einer neuen europäischen Nemoura-Art (Ins. Plecoptera). Revue suisse de zoologie 77 (2): 261-272.

Zwick P., 1973 - Insecta: Plecoptera. Phylogenetisches System und Katalog. Das Tierreich. Eine Zusammenfassung und Kennzeichnung der rezenten Tierformen 94: 32: 1-XXXII, 1-465.

Zwick P., MendL H., 1989 - Notes on Plecoptera (19). Isoperla lugens (Klapalek, 1923), replaces I. alpicola Brinck, 1949. Aquatic Insects: International Journal of Freshwater Entomology 11 (2): 72.

ZWICK P., WeINZIERL A., 1995 - Reinstatement and revision of genus Besdolus (Plecoptera: Perlodidae). Entomologica Scandinavica (Copenhagen) 26: 1-26. 
